\title{
Factors Influencing Perceptions and Expec- tations of Corporate Social Performance in South Africa: An Exploratory Empirical Study
}

\section{A L Coldwell}

School of Economics and Management, University of Natal

\begin{abstract}
This paper analyses the effects of gender and ethnic group in the perceptions and expectations of corporate social performance (CSP) in a sample of students controlled for age, education and academic discipline. Instruments to measure perceptions and expectations of CSP are devised using Likert-type scales. The reliability and construct validity of the measuring instruments are assessed using Cronbach alpha coefficients of internal consistency and factor analysis. A backward elimination multiple regression incorporating dummy variables, indicates that gender and ethnic group are significant predictor variables in perceptions and expectations of CSP. The findings are discussed with regard to the utility of Carroll and Buchholtz's (2000) CSP model in the South African situation.
\end{abstract}

JEL MI4

\section{INTRODUCTION}

The importance of ethics in business has never been greater than today both within South Africa and overseas. Today's business organizations are expected by consumers and society at large to perform a much greater role than in the past. Today business is expected to provide inter alia; a safe and satisfying working environment, a clean extemal physical environment and socioeconomic benefits to the community in which it operates and the social system in which it is located. In order to gain some insight into the perceptions and expectations of corporate social performance (CSP) of South African consumers, it is useful first to examine this phenomenon in a multi-cultural context that is characteristic the South African business situation. It is suggested that a convenient and valid way of doing this is to analyze a group of emerging potential managers such as those that are likely to be found among University third year Commerce students. 
The overriding objectives of this study are:

- to develop instruments to measure perceptions and expectations of CSP, and

- to explore individual variations in the perceptions and expectations of CSP.

It was considered important to control for age and education, as these factors have been shown to be salient in moral development (Kohlberg, 1971 and Kutnick, 1986) and thus are likely to have a strong influence on perceptions and expectations of CSP. Clearly, individuals at different levels of moral development would be expected to have qualitatively different expectations of CSP. Thus controlling for this aspect allows other factors to emerge in the analysis that account for variations in individual perceptions and expectations of CSP.

\section{Carroll and Buchholtz's CSP model}

Carroll and Buchholtz (2000) present a model of the actual and expected CSP gap indicated in Figure 1.

Figure 1 Society's expectations versus business's actual social performance (adapted from Carroll and Buchholtz, 2000)

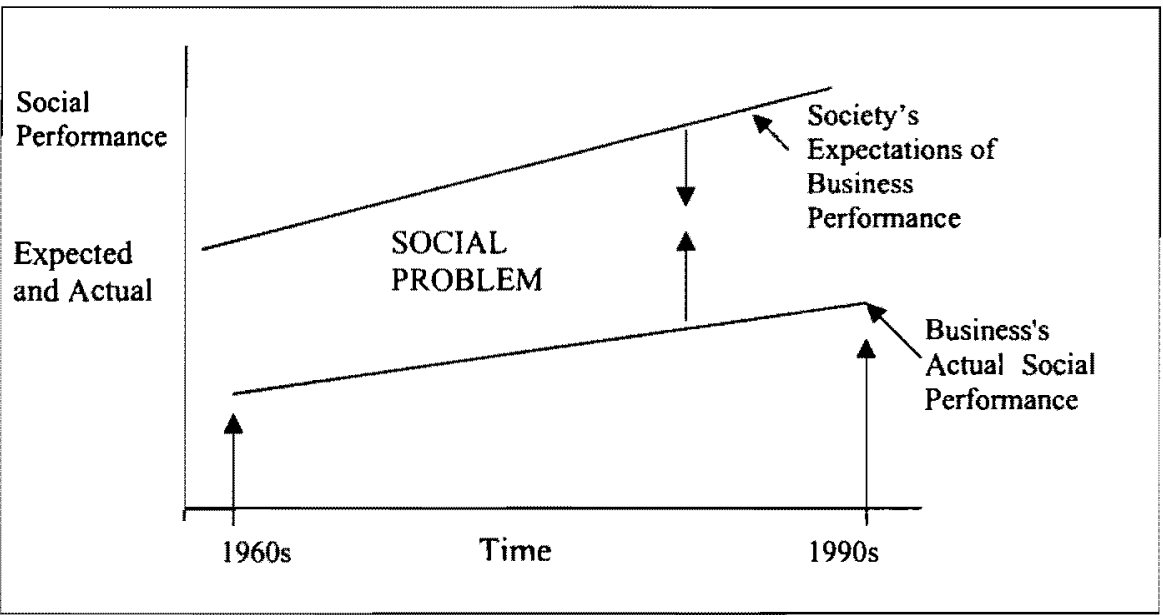

Carroll and Buchholtz (2000) suggest that a revolution of rising expectations has occurred in the west over the past 30 years. This they define as:

$\ldots$ an attitude or a belief that each succeeding generation ought to have a standard of living higher than that of its predecessor and that its expectations of major institutions, such as business, should be greater also. Building on this line of thinking, one could argue that business is criticized today because society's expectations of its performance have outpaced 
business's ability to meet these growing expectations. (Carroll and Buchholtz, 2000; 13).

A social problem is created when a gap exists between society's expectations of socio-economic conditions and present socio-economic realities. At the level of business organizations the social problem becomes the gap between society's expectations of businesses' social performance and its actual social performance. Corporate social performance is defined by Robbins (1994: 123) as: “... A business firm's obligation, beyond that required by the law and economics to pursue long-term goals that are good for society". Boone and Kurtz (1999: 54) define CSP as: “...management's acceptance of the obligation to consider profit, consumer satisfaction, and societal wellbeing of equal value in evaluating the firm's performance." Finally, Wood (1994: 122) defines CSP as: “... a business organization's configuration of principles of social responsibility, processes of social responsiveness and observable outcomes as they relate to the firm's social relationships."

In the current study the concept of CSP is operationally defined as the obligation of businesses operating in South Africa to society and the community beyond their purely legal and economic ones. The concept of CSP as it is used here thus specifically embraces both conducting business ethically and mobilizing business resources for social upliftment. It is maintained that although Carroll and Buchholtz (2000) offer a useful theoretical model at the macro level of analysis, they suggest a degree of homogeneity in individuals' perceptions and expectations of business's social performance that is clearly at loggerheads with circumstantial empirical evidence. Also, their model is confined to a description of circumstances in the developed world and its adequacy, as a descriptor of circumstances in the developing world such as South Africa, neers empirical confirmation.

\section{METHOD}

\section{Research design and sample}

A cross-sectional / correlational research design was used.

A high proportion of accounting students enter business on completion of their studies; with many entering the ranks of management on leaving university. Therefore, all those students studying auditing 3 at a university situated in KwaZulu-Natal were selected for the sampling frame $(\mathrm{N}=260)$ and a representative sample of 133 students consisting of 28 white, 29 black and 76 Indian students were ultimately used. Four coloured students were not included because they comprised too small a sample for analysis. There were 67 male and 
66 female students in the sample. The remaining students were lost through nonresponse, non-attendance and incomplete/incorrect completion of the questionnaire.

The research design incorporated controls for age and education.

As regards age, $79 \%$ of the students in the sample were 19 to 21 years of age, with $93 \%$ of students being between 19 and 22 years old.

Education was controlled by means of the students selected in the sample having achieved roughly the same level of competence in a specific university discipline. The selection of university students studying the same subject matter suggests a degree of homogeneity in their cognitive ability /intelligence which had also been identified by Kutnick (1986) as a salient factor in moral development.

Finally, commerce students might also be expected to have more focused perceptions and expectations of what constitutes CSP than those studying noncommercial disciplines.

\section{The questionnaire and measuring instruments}

A self-completion questionnaire consisting of biographical items and specific instruments for measuring perceptions and evaluations of moral business behaviour was used. The questionnaire was distributed to students before the start of an Auditing 3 lecture. Also a brief preamble regarding its purpose, method of completion and an assurance of confidentiality were given. Biodata included: age, gender and ethnic group.

A Likert-type format with items arranged on 5 point scales ranging from "strongly agree" to "strongly disagree" was devised to measure perceptions (MORPER) and expectations (MOREXPEC) of CSP. The MORPER measuring instrument was adapted from a scale used by Trevino and Nelson (1995), while the author developed the MOREXPEC instrument with assistance from honours students at the university. Examples of MORPER items which tried to focus on perceptions of the actual or "is" business situation are: "Business persons only care about making a profit" and "The profit motive pressures managers to compromise their ethical concerns". Examples of MOREXPEC items which aimed to uncover expectations of corporate social performance are: "Business must spend more on social upliftment" and "An ethical business is one where moral business behaviour is conducted in spite of lower profits for the company". 


\section{Statistical techniques}

The study incorporated analyses of multiple regressions, internal consistencies and factor structures. A brief overview of the psychometric properties of the measuring instruments as regards their internal consistency and construct validity is required, given the fact they are newly composed and untested.

\section{THE FINDINGS OF THE STUDY}

\section{Reliability and validity analyses}

Cronbach alpha coefficients were obtained for the MOREXPEC and MORPER measuring instruments after the initial number of 20 items had been reduced to 6 items in each scale. After deleting the items recommended in the analysis, alpha coefficients of the following magnitude were obtained:

MOREXPEC $=0.71$

MORPER $=0.78$

Both measuring instruments used in the study thus attained acceptable levels of internal consistency.

Factor analysis of the measuring instruments was conducted to obtain some insight into the construct validity of the MOREXPEC and MORPER measuring instruments.

A Kaiser Meyer-Olkin measure of sampling adequacy of 0.678 was obtained which is considered "middling" (Kaiser and Rice, 1974) on a scale of 0 to 1, but was considered acceptable for an exploratory investigation. A principal component method of factor extraction was adopted and an oblimin rotation with Kaiser normalization used. A non-orthogonal rotation method was used because it seemed reasonable to use an approach that would test the conceptual underpinnings of the MOREXPEC and MORPER constructs more rigorously.

Only factors with eigenvalues greater than 1.0 were removed in line with the roots criterion. The variance explained by the five components conforming to this criterion was $66 \%$. Only items loading 0.33 and above were interpreted after rotation as this generated a simpler structure. The items with the largest loadings under factors 1 and 3 of the rotated solution suggested that the underlying dimension explained by both could be interpreted as the perception of actual CSP. (Thus confirming the original construct MORPER.) 
Factor 2 loaded above 0.33 on 5 of the 6 items of the MOREXPEC scale. Therefore the validity of the original construct was confirmed and interpreted as individual expectations of CSP.

\section{Multiple regression analyses}

Multiple regression analyses were used to find the best biodata predictors of respondents $=$ scores on the MOREXPEC and MORPER measuring instruments. The assumption of normally distributed residuals was investigated using normal probability plots of regression standardized residuals for both dependent variables and expected normal and observed values approximated a straight line in both instances. However, a degree of multicollinearity was encountered in the independent variable "Indian" where a Cramer's V association in excess of 0.5 , $p<0.01$ was found between it and the "black" and "white" independent variables. However, it was decided to include the Indian variable in the regression as it comprised a large section of the sample and explained additional variance of both the MOREXPEC and the MORPER dependent variables than in the regression equations when it as excluded from the analysis.

A stepwise backward elimination multiple regression technique was used with ethnic groups and gender entered as dummy variables in the analysis.

Tables 1-3 indicate the findings of the multiple regression analysis with MOREXPEC as the dependant variable.

\section{Table 1 Model summary}

\begin{tabular}{|l|l|c|c|c|}
\hline Model & R & R Square & $\begin{array}{l}\text { Adjusted } \\
\text { square }\end{array}$ & $\begin{array}{l}\text { Std error of the } \\
\text { estimate }\end{array}$ \\
\hline 1 & $.290^{\mathrm{a}}$ & .084 & .057 & 5.8255 \\
\hline 2 & $.289^{\mathrm{b}}$ & .083 & .064 & 5.8060 \\
\hline 3 & $.279^{\mathrm{c}}$ & .078 & .065 & 5.8031 \\
\hline
\end{tabular}

${ }^{3}$ Predictors: (Constant), white, gender black, indian

Predictors: (Constant), gender, black, indian

' Predictors: (Constant), black, indian 


\section{Table 2 Anovas}

\begin{tabular}{|c|c|c|c|c|c|}
\hline Model & $\begin{array}{c}\text { Sum of } \\
\text { squares }\end{array}$ & df & $\begin{array}{c}\text { Mean } \\
\text { square }\end{array}$ & $\mathbf{F}$ & Sig. \\
\hline $\begin{array}{ll}1 \text { Regression } \\
\text { Residual } \\
& \text { Total } \\
\end{array}$ & $\begin{array}{r}428.684 \\
4683.204 \\
5111.888 \\
\end{array}$ & $\begin{array}{r}4 \\
138 \\
142\end{array}$ & $\begin{array}{r}107.171 \\
33.936\end{array}$ & 3.158 & $.016^{\mathrm{a}}$ \\
\hline 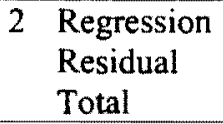 & $\begin{array}{r}426.301 \\
4685.587 \\
5111.888 \\
\end{array}$ & $\begin{array}{r}3 \\
139 \\
142\end{array}$ & $\begin{array}{r}142.100 \\
33.709\end{array}$ & 4.215 & $.007^{b}$ \\
\hline $\begin{array}{ll}3 \text { Regression } \\
\text { Residual } \\
\text { Total }\end{array}$ & $\begin{array}{r}397.257 \\
4714.632 \\
5111.888\end{array}$ & $\begin{array}{r}2 \\
140 \\
142\end{array}$ & $\begin{array}{r}198.628 \\
33.676\end{array}$ & 5.898 & $.003^{c}$ \\
\hline
\end{tabular}

${ }^{2}$ Predictors: (Constant), white, gender black, indian

Predictors: (Constant), gender, black, indian

'Predictors: (Constant), black, indian

Table 3 Coefficients

\begin{tabular}{|c|c|c|c|c|c|c|}
\hline & \multirow{2}{*}{ Model } & \multicolumn{2}{|c|}{$\begin{array}{c}\text { Unstandardized } \\
\text { coefficients }\end{array}$} & \multirow{2}{*}{$\begin{array}{l}\text { Standar- } \\
\text { dized } \\
\text { coefficients }\end{array}$} & \multirow{2}{*}{$\mathbf{t}$} & \multirow{2}{*}{ Sig. } \\
\hline & & B & $\begin{array}{l}\text { Std. } \\
\text { error }\end{array}$ & & & \\
\hline \multirow[t]{5}{*}{1} & (Constant) & 21.567 & 1.912 & & 11.283 & .000 \\
\hline & Gender & -.934 & 1.020 & -.916 & .361 & \\
\hline & Indian & 2.842 & 1.963 & .237 & 1.448 & .150 \\
\hline & Black & 4.142 & 2.153 & .279 & 1.924 & .056 \\
\hline & White & -.569 & 2.147 & -.038 & -.265 & .791 \\
\hline \multirow[t]{4}{*}{2} & (Constant) & 21.153 & 1.097 & & 19.290 & .000 \\
\hline & Gender & -.943 & 1.016 & -.079 & -.928 & .355 \\
\hline & Indian & 3.260 & 1.167 & .272 & 2.794 & .006 \\
\hline & Black & 4.563 & 1.447 & .307 & 3.154 & .002 \\
\hline \multirow[t]{3}{*}{3} & (Constant) & 20.632 & .941 & & 21.916 & .000 \\
\hline & Indian & 3.421 & 1.153 & .286 & 2.967 & .004 \\
\hline & Black & 4.368 & 1.431 & .294 & 3.053 & .003 \\
\hline
\end{tabular}

The best solutions for the MOREXPEC dependant variable, in tems of $\mathrm{R}$ square, significance of $t$ and significance of $F$ were obtained in steps 2 and 3 of the analysis.

In step 2 only $8 \%$ of the variation of MOREXPEC scores was explained by gender and ethnic group variables (black and Indian) with $\mathrm{R}^{2}=8.3 \%$, 
$\mathrm{R}^{2}$ (adj) $=6.4 \%$ ). Analysis of variance indicated that $\mathrm{F}=4.215, \mathrm{p}=0.007$ for the model. However, the $t$ value of the coefficient for gender was not significant at the 5 percent level $(t=-0.916, p=0.355)$, but was significant for ethnic groups (black and Indian) with $t=3.154, p=0.002$ and $t=2.794, p=0.006$ respectively.

In step 3, a similarly small percentage of variance was explained by ethnic groups (Indian and black); $\mathrm{R}^{2}=7.8 \%, \mathrm{R}^{2}(\mathrm{adj})=6.5 \%$. Analysis of variance indicated that $F=5.989, p=0.003$ and the $t$ values for ethnic groups (Indian and black) were significant with $t=2.967, p=0.004$ and $t=3.053, p=0.003$ respectively.

The small amount of variance of MOREXPEC explained by the biodata in the equation might be expected given the variance explained by age and education in moral development (Kutnick, 1986) and thus individual perceptions and expectations of corporate social performance. Tables 4-6 present the multiple regression analysis with MORPER as the dependant variable.

\section{Table 4 Model summary}

\begin{tabular}{|l|c|c|c|c|}
\hline Model & $\mathbf{R}$ & R Square & $\begin{array}{c}\text { Adjusted R } \\
\text { square }\end{array}$ & $\begin{array}{c}\text { Std error of the } \\
\text { estimate }\end{array}$ \\
\hline 1 & $.329^{\mathrm{a}}$ & .108 & .082 & 7.5643 \\
\hline 2 & $.329^{\mathrm{b}}$ & .108 & .089 & 7.5375 \\
\hline
\end{tabular}

"Predictors: (Constant), white, gender black, indian

${ }^{b}$ Predictors: (Constant), white, gender, indian

Table 5 Anovas

\begin{tabular}{|c|c|c|c|c|c|}
\hline Model & $\begin{array}{l}\text { Sum of } \\
\text { squares }\end{array}$ & df & $\begin{array}{l}\text { Mean } \\
\text { square }\end{array}$ & $\mathbf{F}$ & Sig. \\
\hline $\begin{array}{ll}1 & \text { Regression } \\
\text { Residual } \\
\text { Total }\end{array}$ & $\begin{array}{r}956.520 \\
7896.138 \\
8852.657\end{array}$ & $\begin{array}{r}4 \\
138 \\
142\end{array}$ & $\begin{array}{r}239.130 \\
57.218\end{array}$ & 4.179 & $.003^{\mathrm{a}}$ \\
\hline $\begin{array}{l}2 \text { Regression } \\
\text { Residual } \\
\text { Total }\end{array}$ & $\begin{array}{r}955.589 \\
7897.068 \\
8852.657\end{array}$ & $\begin{array}{r}3 \\
139 \\
142\end{array}$ & $\begin{array}{r}318.530 \\
56.813\end{array}$ & 5.607 & $.001^{b}$ \\
\hline
\end{tabular}

"Predictors: (Constant), white, gender black, indian

${ }^{b}$ Predictors: (Constant), white, gender, indian 


\section{Table 6 Coefficients}

\begin{tabular}{|c|c|c|c|c|c|c|}
\hline \multirow{2}{*}{\multicolumn{2}{|c|}{ Model }} & \multicolumn{2}{|c|}{$\begin{array}{c}\text { Unstandardized } \\
\text { coefficients }\end{array}$} & \multirow{2}{*}{$\begin{array}{l}\text { Standar- } \\
\text { dized } \\
\text { coefficients }\end{array}$} & \multirow{2}{*}{$\mathbf{t}$} & \multirow{2}{*}{ Sig. } \\
\hline & & B & $\begin{array}{l}\text { Std. } \\
\text { error }\end{array}$ & & & \\
\hline \multirow[t]{5}{*}{1} & (Constant) & 22.791 & 2.482 & & 9.182 & .000 \\
\hline & Gender & -2.982 & 1.325 & -.189 & -2.251 & .026 \\
\hline & Indian & 3.728 & 2.549 & .236 & 1.462 & .146 \\
\hline & Black & -.356 & 2.795 & -.018 & -.128 & .899 \\
\hline & White & 3.842 & 2.788 & .194 & 1.378 & .171 \\
\hline \multirow[t]{4}{*}{2} & (Constant) & 22.540 & 1.510 & & 14.930 & .000 \\
\hline & Gender & -3.003 & 1.310 & $-.19 !$ & -2.292 & .023 \\
\hline & Indian & 3.987 & 1.539 & .253 & 2.590 & .011 \\
\hline & White & 4.104 & 1.874 & .207 & 2.190 & .030 \\
\hline
\end{tabular}

The best solution for the MORPER dependent variable was obtained in step 2 where gender and ethnic groups (white and Indian) were found to be the best predictors $\left(\mathrm{R}^{2}=10.8 \%, \mathrm{R}^{2}(\operatorname{adj})=8.9 \%\right)$. Analysis of variance indicated $\mathrm{F}=5.607$, $p=0.001$. The $t$ value of the coefficient for gender was significant at less than the five percent level $(p=0.02$ ), while the values for ethnic groups (white and Indian) were significant, $\mathrm{p}=<0.05$ in both cases.

In short, the regression analysis suggested that being a member of the black and Indian ethnic groups best predicted scores on the MOREXPEC dependent variable. Also the analysis indicated that gender and ethnic group (white and Indian) were the best predictors of scores on the MORPER dependent variable.

In sum, the multiple regression analyses have shown the importance of gender and ethnic group in predicting scores on the dependent variables. The implications of this finding in terms of the theoretical model put forward by Carroll and Buchholtz (2000) is investigated further in the following section that summarizes respondents' mean scores on the dependent variables.

Respondents' mean scores on the MOREXPEC and MORPER measuring instruments

Table 7 summarizes the mean scores of the respondents on the MOREXPEC and the MORPER measuring instruments. 
Table 7 Morexpec and Morper mean scores by gender and ethnic group

\begin{tabular}{|l|r|r|r|r|r|r|r|r|r|}
\hline \multirow{2}{*}{$\begin{array}{l}\text { Ethnic } \\
\text { group }\end{array}$} & \multicolumn{3}{|c|}{ Male } & \multicolumn{4}{c|}{ Female } & \multicolumn{3}{c|}{ Total } \\
\cline { 2 - 10 } & $\begin{array}{c}\text { Mean- } \\
\text { expec }\end{array}$ & $\begin{array}{c}\text { Mean } \\
\text { mor- } \\
\text { per }\end{array}$ & $\mathbf{n}$ & $\begin{array}{c}\text { Mean } \\
\text { mor- } \\
\text { expec }\end{array}$ & $\begin{array}{c}\text { Mean } \\
\text { mor- } \\
\text { per }\end{array}$ & $n$ & $\begin{array}{c}\text { Mean } \\
\text { mor- } \\
\text { expec }\end{array}$ & $\begin{array}{c}\text { Mean } \\
\text { mor- } \\
\text { per }\end{array}$ \\
\hline White & 16 & 20.7 & 24.0 & 12 & 20.0 & 26.0 & 28 & 20.35 & 25 \\
\hline Black & 22 & 25.3 & 19.0 & 7 & 23.8 & 24.0 & 29 & 24.5 & 21.6 \\
\hline Indian & 29 & 22.6 & 23.0 & 47 & 24.8 & 26.8 & 76 & 23.7 & 24.9 \\
\hline Total & 67 & 22.8 & 22 & 66 & 22.8 & 25.6 & $133^{*}$ & 22.8 & 23.8 \\
\hline
\end{tabular}

*NB the 4 coloured students were excluded from the analysis because the group was considered too small to analyze; 6 students had missing information and could not be included in the analysis.

Table 1 indicates that females on average obtain identical MOREXPEC scores to males. However, females score a higher mean score on the MORPER measuring instruments than males. The data was subjected to paired sample $t$ tests to ascertain significant differences between scores on the measuring instruments.

Differences between perceptions and expectation mean scores are particularly evident for white females (MORPER $>$ MOREXPEC $=6, t=2.65, p=0.02$ ). This suggests that for white females business in South Africa is perceived as acting socially responsibly. In fact, these groups seem to regard business as going beyond the call of duty or, in other words, what it ought to be doing in terms of its social responsibility.

Table 1 also indicates that the difference between expectation and perception mean scores are largest for black males (MOREXPEC $>$ MORPER $=6.3, t=-3.08$, $\mathrm{p}=0.006$ ). This suggests that black respondents feel that business ought to be doing more in fulfilling its social responsibilities than it is perceived to be doing currently.

\section{DISCUSSION OF THE FINDINGS}

The findings suggest that variations in individual perceptions and expectations of CSP are evident in a sample of third year university students. The multiple regression analyses and paired group $t$ tests have indicated that gender and ethnic group affect perceptions and expectations of CSP when defined in terms of doing business in an ethical manner and using business resources for social upliftment. This would suggest that it is therefore problematical to regard 
peoples' perceptions and expectations of CSP as being consistently uniform as suggested by Carroll and Buchholtz's (2000) model. The study has shown quite clearly that interpersonal variations do exist in perceptions and expectations of CSP between males, females and members of different ethnic groups. However, the external validity of these findings is tentative and further studies incorporating larger samples with different sampling frames are required to be able to do this. Also, the amount of variance explained by the regression models is small and other independent variables such as socio-economic status, work experience and others need to be investigated. The findings suggest that there are at least two distinct perspectives of CSP in the South African situation, which correspond approximately to two specific theoretical approaches. On the one hand Friedman (1970) suggests that business is exclusively business. Business should concentrate on making profits rather than behaving ethically, so long as it remains within the law. It is not the responsibility of business to uplift the community. This is the concern of government which, was elected to perform this role and to which business pays its taxes. On the other hand there exists the socialist view that business's overriding focus must be to serve the community and to use its resources primarily, if not wholly for this purpose. However, apart from these two views there is a third view that embraces the modern view of business ethics. This is that business is indeed in business to make profits, but that such profit-making should not be seen as an end in itself. Business must also behave morally and with a sense of social responsibility, not only to fulfill its moral obligations to the community in which it is inextricably entwined, but also to flourish as a business in a socially aware milieu. This view sometimes called the socioeconomic view (Robbins, 1994), suggests that: "maximizing profits is a company's second priority not its first. The first is ensuring its survival" (Gellerman, 1986: 89).

The findings suggest that black males and females feel that business ought to be more socially responsible than it is currently. Blacks in this exploratory study at least, seem to hold either a socialist or socioeconomic view of business. Whites see business as behaving with more social responsibility than is strictly required of it. They thus appear to endorse the "business of business is business" paradigm expounded by Friedman (1970).

\section{CONCLUSION}

This exploratory study using hitherto untried instruments on a relatively small sample controlled for age and education, indicates that gender and ethnic group have a significant effect on perceptions and expectations of corporate social performance in South Africa. 
The study reveals that blacks expect business to play a more socially responsible role in South Africa than it does currently. Whites view business as doing more in terms of social responsibility than is required from a strictly business point of view. These findings are important in so far as they have shown in a fairly rigorous empirical research design, that gender and ethnic group are independent variables in the explanation of perceptions and expectations of CSP. Also the findings have suggested that Carroll and Buchholtz's (2000) theoretical model that indicates expectations of CSP as being uniformly and consistently above actual perceptions of CSP, may not be valid in the South African situation.

From a practical point of view, the findings also indicate that an emerging elite of future black managers perceives South African businesses as under-performing socially. Business needs to take cognizance of this problem and to explore further how it can upgrade its CSP, as persistent neglect may ultimately affect its financial performance detrimentally.

\section{ENDNOTE}

The author acknowledges with gratitude the assistance of Ms V. Ireland, Ms S. Khatree and $\mathrm{Mr} \mathrm{C}$. Hubbertson in the research process.

\section{REFERENCES}

1 BOONE, L.E. and KURTZ, D.L. (1994) Business and Society, New York: Harper Collins.

2 CARROLL, A.B. and BUCHHOLTZ, A.K. (2000) Business and Society: Ethics and Stakeholder Management, United States: South-Western.

3 FRIEDMAN, M. (1970) "The Social Responsibility of Business is to Increase its Profits", in WHITE, T.I., Business Ethics, New York: Macmillan.

4 GELLERMAN, S.W. (1986) "Why 'Good' Managers Make Bad Ethical Choices", in ROBBINS, S.P. Management, New Jersey: Prentice-Hall.

5 KAISER, H.F. and RICE, J. (1974) "Little Jiffy Mark IV", Educational and Psychological Measurement, 34:111-17.

6 KOHLBERG, L. (1969) "Stages and Sequence: the CognitiveDevelopmental Approach to Socialization", in GOSLIN, D.A. (ed.) Handbook of Socialization Theory and Research, Chicago: Rand McNally. 
7 KUTNICK, P. (1986) "The Relationship of Moral Judgement and Moral Action; Kohlberg's Theory, Criticism and Revision", in Modgil, J. and Modgil, C. (eds.) Lawrence Kohlberg: Consensus and Controversy, Basingstoke: The Falmer Press.

8 ROBBINS, S.P. (1994) Management, New Jersey: Prentice-Hall.

9 TREVINO, L.K. and NELSON, K.A. (1995) Managing Business Ethics, New York: John Wiley.

10 WOOD, D.J. (1994) Business and Society, New York: Harper Collins. 